The Daily Nevs, referring to a visit to the Chichester training-ship, lying off Greenhithe, says there was one drawback to the pleasure of the trip- "it was the horrid stench of the Southern outfall."

THE deaths in Sheffield last week were at the rate of 35 per 1000 annually. Small-pox caused 15 deaths, in addition to a considerable mortality from measles and diarrhcea.

Mr. Grots has been elected President of University College in the place of the late Lord Brougham. The name of Lord Belper was mentioned for the appointment, but he resigned his claim in favour of the eminent historian.

Trez Earl of Carnarvon has accepted the Presidency of the Social Science Association for the Birmingham meeting.

Tre Town Council of Salford has appointed Mr. E. J. Syson, C.R.C.P. Edin., the medical officer of health for the borough.

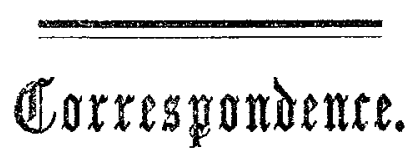

“Audi alteram partem."

\section{MEDICAL INFORMATION ON CAUSES OF DEATH.}

To the Editor of THE LANCET.

SIR,-I entirely concur in the course taken in regard to "Certificates of Death" in hospital practice by Dr. Buchanan and the Children's Hospital. But I think there is no need to introduce the complication of a second form. The old one can be readily altered, according to the circumstances of any particular case. I have, from the very commencement of my hospital work, acted upon the plain principle of certifying to what 1 knew, and no more. No law, statutory or of red tape, can require a man to go beyond this. In the case therefore of being called upon to certify concerning the death of an outpatient whom I have only seen in the hospital consultingroom, my practice has always been to fill in the form as follows :-

"I hereby certify that I attended Sarah $\mathrm{C}-$ - aged five last birthday; that I last saw her on March 20th, 1868; that she is said to have died on March 25th, 1868, at

and that the cause of her death was presumed to be hydrocephalus."

I thus avoid the responsibility of attesting a death which may not have taken place; and simply state the presumption as to the cause, taken from the hospital register, in which the disease for which the patient is treated is entered. On one occasion only has a registrar thought fit to object to my mode of filling up the certificate. I did not alter it to suit his views.

There is another kind of certificate for which hospital physicians are often applied to. The experience of others must, I think, agree with mine, that many persons apply for advice mainly, if not entirely, in order to get certificates that they are suffering from disease which prevents them from working, so as to qualify them to claim relief from clubs, \&c. Certificates of this kind I simply decline to give, for two reasons, each to my mind sufficient. Firstly, a physician cannot fairly be taxed to do more than treat disease ; he ought not to be expected to incur the additional loss of time and responsibility attached to giving certificates. Secondly, clubs and similar bodies ought for their own good management to employ medical officers to report upon all cases of sickness amongst members, and, of course, to pay them. Hospital officers ought not, it appears to me, by doing this work for clubs gratuitously, to deprive other practitioners of their fees.

The subject of certificates of death and certificates of sickness was discussed in leading articles in The Larcet some years ago.

I am, Sir, your obedient servant,

Finsbury-square, July, 1868.

\section{THE COLLEGE OF PHYSICIANS. To the Editor of THE LANCET.}

SIR, - Your admirable remarks on the nomination of Fellows at the Royal College of Physicians are quite true ; but it is to be feared they will not bear much fruit. "It is a disgrace to the Council" to pass over the men they annually pass over, and to recommend those they do recommend for the Fellowship. Yet the Council as a body can bear to be guilty of dis. graceful acts which the individuals composing it would be afraid to do if their names were known. The hole-and-corner proceedings of this irresponsible body ought long since to have been put a stop to. It is simply monstrous that a public institution should be managed as this College is managed. There is but one remedy, and it is that the proceedings should be thrown open to the light of day. Admit the press within the council-room. The men who are now not ashamed to do disgraceful acts would then pursue a different course when they knew that their words and actions could be criticised by the honourable members of the profession. Just as hospital reform dates from the time when THE LANCET forced its way into these charitable institutions, so until your reporter can claim admission into the dreary College in Pall-mall, matters will remain as miserable and contemptible as they are now.

July, 1868. I am, Sir, your obedient servant,

M.D.

\section{THE SUPPLY OF WATER TO THE WINDSOR} CAVALRY BARRACKS.

To the Editor of THE LANCET.

SIR,-Will you please insert in your next number my con. tradiction to your report that the supply of water to the Cavalry Barracks at Windsor is disgraceful. The meters show beyond dispute that between thirty and forty gallons of water a head is supplied in each twenty-four hours for every man, woman, child, and horse. Analysis shows this water is of good quality. As to the apparatus for receiving this supply, that is another matter, and not my affair.

I am, Sir, your obedient servant, Windsor and Eton Waterworks

W. H. CUTLER. July 6 th, 1868 .

* In answer to the above, we have only to refer our readers to the facts observed. The latrines and stables were imperfectly flushed, and many of the taps were dry. We cannot pretend to explain the cause, which may be due to escape or imperfect distribution. We made no attack on the quality of the water supplied.

\section{FOUR AT A BIRTH.}

To the Editor of THE LANCET.

SIR,-I send you, from its comparative rarity, the following for insertion, should you deem it worthy of record. I was called at half-past five this morning to attend a Mrs. Gof this place, aged twenty-three years, in her third confinement, who was very shortly delivered of four fine healthylooking female children, at the full period. The first was born with the usual head presentation, the others being footlings. The placenta was en masse, the umbilical cords having each distinct origins. Considerable flooding ensued, accompanied with very alarming syncope. Uterine contraction was fortunately induced without much difficulty.

I am, Sir, your obedient servant, Chatham, Julg 7th, 1863.

E. A. STEDdr.

\section{THE FRUIT SEASON AND THE INCREASE OF DEATHS FROM DIARRHCEA.}

\section{To the Editor of THE LANCE'r.}

SIR,-The mortality from diarrhea is rapidly increasing. By the Registrar-General's report just published the deaths from this cause alone last weels were 121 , as agairst 66 and 31 the two previous weeks.

Last week's report ascribed the increase of the mortality from diarrhoe to the heat of the weather; this week the 